International Journal of Environment, Agriculture and Biotechnology
Vol-6, Issue-6; Nov-Dec, 2021
J Journal Home Page Available: https://ijeab.com/
Journal DOI: $10.22161 /$ ijeab

Peer Reviewed

\title{
Influence of different Temperatures and Substrates on the Germination of Munguba (Pseudobombax munguba (Mart. \& Zucc.) Dugand.)
}

\author{
Antenor P. Barbosa ${ }^{1 *}$; Michele Braule P. R. de Oliveira ${ }^{2}$; Adrielly O. Pereira ${ }^{3}$ \\ ${ }^{1}$ Researcher, Dr. National Institute of Amazonian Research - Technology and Innovation Coordination. INPA/COTEI - Manaus, AM \\ ${ }^{2}$ M.Sc, National Institute for Amazonian Research - Technology and Innovation Coordination. INPA/COTEI - Manaus, AM \\ ${ }^{3}$ B.Sc. Amazonas State University - UEA. Department of Biology. Biological Sciences Degree. Manaus, AM \\ * Corresponding author
}

Received: 06 Oct 2021; Received in revised form: 18 Dec 2021; Accepted: 26 Dec 2021; Available online: 31 Dec 2021

(C)2021 The Author(s). Published by Infogain Publication. This is an open access article under the CC BY license

(https://creativecommons.org/licenses/by/4.0/).

\begin{abstract}
Due to the ecological and economic importance of the species Pseudobombax munguba (Mart. \& Zucc.) Dugand. (Munguba), it is necessary to investigate the most appropriate conditions for conducting its germination process. Therefore, the objective of this work was to evaluate seed moisture, number of seeds/kg, and the influence of different temperatures and substrates on the process of seed germination. The initial seed moisture was evaluated with samples containing four replicates of 10, 20, 30, 50, 60, 70, 80, 90 and 100 seeds dried in an oven at $105 \pm 3^{\circ} \mathrm{C}$. Germination was tested in three different substrates: sand, vermiculite, and Germitest ${ }^{\circledR}$ paper rolls (three sheets/roll) at constant temperatures of 25,30 and $35^{\circ} \mathrm{C}$ in a germination chamber. The number of 50 seeds per replicate had more homogeneous representation with $7.2 \%$ moisture. Sand or vermiculite substrates at a temperature of $25^{\circ} \mathrm{C}$ can be indicated to conduct the germination of the species under controlled conditions. Germination rates in sand substrate reached 69\% when assessed for root protrusion, and $53 \%$ for seedling formation. Germination rates in vermiculite were $74 \%$ for root protrusion and $56 \%$ for seedling formation. The initial development was homogeneous and there were higher rates of germination speed in both substrates when assessing seedling formation.
\end{abstract}

Keywords-Central Amazon, normal seedlings, root protrusion, seed moisture.

\section{INTRODUCTION}

Knowing the proper conditions for seed germination is of great importance, since species can present different responses to several intrinsic factors such as dormancy, and extrinsic factors such as water, light, temperature, oxygen and the action of pathogens associated with the substrate for germination (Ferreira and Borguetti, 2004; Brazil, 2009). These authors mention that among the external factors that directly affect the germination process, temperature and substrate exert significant influence, which can have an effect on the establishment of plant communities.

Pseudobombax munguba (Mart. \& Zucc.) Dugand. is a tree species of the family Malvaceae, which is typical of the Amazonian floodplains (Gribel and Gibbs,
2002; Gribel, 2003). Its seeds are consumed by the local fauna and its wood is used in the production of paper, boats and housing (Maia, 2001), thus making this species relevant for the riverside communities in the Amazon, who mostly build their houses along the banks of rivers and streams, and mainly use boats and canoes as their main means of transportation.

In view of the ecological, economic and social importance of the species, it is necessary to further the knowledge of the most appropriate conditions for conducting its germination process and ensuring the production of seedlings for timber plantations and/or enrichment of areas along the watercourses in the Amazon. Thus, the objective of this work was to evaluate the 
influence of temperature and substrate on the germination process of $P$. munguba seeds.

\section{MATERIALS AND METHODS}

The fruits used in this study were collected directly from the canopy of trees, with the aid of trimmers, when they began to naturally fall during the third week of August in the lowland areas $\left(03^{\circ} 03^{\prime} 40.0^{\prime \prime} \mathrm{S}-60^{\circ} 06^{\prime} 36.1^{\prime \prime} \mathrm{W}\right)$. The collection period took place at the end of the rainy season. As this species is typical of the floodplains of the Amazon region, its fruiting occurs from June to September (Gribel, 1995; Gribel and Gibbs, 2002; Gribel, 2003).

The degree of moisture of the seeds was defined with samples containing four replicates of 10, 20, 30,40 (eliminated from the experiment due to an accidental occurrence and damage during manipulation in the oven), 50, 60, 70, 80, 90 and 100 seeds, which were placed in aluminum cans $(6 \times 5 \mathrm{~cm}$ - diameter/height $)$ after the evaluation of their initial mass before drying. The opened cans were taken to drying in an oven at $105 \pm 3^{\circ} \mathrm{C}$, according to Brasil (2009). Cooling was performed in a desiccator containing blue silica.

Analyses to determine the degree of moisture of the seeds were carried out in a completely randomized design, with the analysis of variance of treatments (ANOVA). The mean values were compared by Tukey's test at the level of $5 \%$ probability (Santana and Ranal, 2004).

The effects of different substrates and temperatures on seed germination were evaluated in Table 1 - Seed moisture (\%) of Pseudobombax munguba (Mart. \& Zucc.) Dugand., obtained with different numbers of seeds per sample.

\begin{tabular}{clcccc}
\multicolumn{7}{c}{ per sample. } \\
\hline Samples & Means (\%) & Minimum (\%) & Maximum (\%) & $\begin{array}{c}\text { Standard } \\
\text { Deviation }\end{array}$ & $\begin{array}{c}\text { Difference between } \\
\text { replicates }(\%)\end{array}$ \\
\hline 10 & $8.5 \mathrm{~A}$ & 7.4 & 9.8 & 1.07 & 2.4 \\
20 & $7.6 \mathrm{AB}$ & 7.4 & 7.9 & 0.26 & 0.5 \\
30 & $7.3 \mathrm{AB}$ & 7.0 & 7.6 & 0.28 & 0.6 \\
50 & $7.2 \mathrm{AB}$ & 7.0 & 7.3 & 0.13 & 0.3 \\
60 & $7.4 \mathrm{AB}$ & 6.9 & 8.6 & 0.78 & 0.4 \\
70 & $7.1 \mathrm{AB}$ & 6.9 & 7.3 & 0.17 & 0.2 \\
80 & $7.0 \mathrm{~B}$ & 6.9 & 7.1 & 0.08 & 0.3 \\
90 & $7.0 \mathrm{~B}$ & 6.9 & 7.2 & 0.13 & 0.3 \\
\hline
\end{tabular}

C. V.: 8.18\%. Means followed by the same capital letter in the column do not differ statistically from each other by Tukey's

test at $5 \%$ probability.
Gerbox ${ }^{\circledR}$ boxes containing sand, vermiculite or Germitest $\AA$ paper rolls (three sheets/roll), with four replications of 25 seeds per treatment. The boxes were wrapped in transparent plastic bags, closed, and placed in germinators, at constant temperatures of 25,30 and $35^{\circ} \mathrm{C}$, with a photoperiod of 12 $\mathrm{h}$ of light/dark (10 $\mu \mathrm{mol} \mathrm{m} \mathrm{m}^{-1} \mathrm{~s}^{-1}$ of radiation).

The criteria to consider a seed as germinated were primary root protrusion (approximately $2 \mathrm{~mm}$ in length) and seedling formation, according to Brasil (2009). Germination was evaluated by the percentage of germinated seeds, mean germination time (days), and Germination Speed Index - GSI, according to Maguire (1964), and Santana and Rana (2004). The experimental design used was completely randomized in a 3 x 3 factorial scheme (three temperatures and three substrates). Statistical analyses were performed using analysis of variance (ANOVA), and means were compared by Tukey's test at the level of 5\% probability (Santana and Ranal, 2004).

\section{RESULTS}

The species $P$. munguba has an average seed weight of $0.01888 \mathrm{~g}, 1000$ seed weight of $18,88475 \mathrm{~g}$, and number of seeds $/ \mathrm{kg}$ of 52,953.

Seed moisture ranged between 6.8 and $8.5 \%$, with the highest value occurring in the treatment with 10 seeds. The lowest values were observed in the treatments with 100, 90 and 80 seeds, which showed no differences by Tukey's test. However, there were no significant differences between treatments with 20,30, 50, 60 and 70 and all other treatments (Table 1). 
The moisture content of $7.2 \%$ in the 50 -seed treatment showed the lowest standard deviation $(0.13 \%)$ in the intermediate group of treatments, with no significant differences between them and all other treatments. Differences between replicates ranged from 0.2 to $2.4 \%$ between all treatments. The 50-seed treatment had a difference of $0.3 \%$ from the others. These results show that a treatment with 50 seeds is more representative for evaluating the moisture content of $P$. munguba seeds.

The germination rates for root protrusion in $P$. munguba seeds in sand substrate at temperatures of $25^{\circ} \mathrm{C}$, $30^{\circ} \mathrm{C}$, and $35^{\circ} \mathrm{C}$ were respectively 69,66 , and $71 \%$; in paper rolls, 64, 71, and 65\%; and in vermiculite, 74, 60, and $65 \%$. In the sand substrate there was a reduction in germination at $30^{\circ} \mathrm{C}$, however, it was similar at $25^{\circ} \mathrm{C}$ and $30^{\circ} \mathrm{C}$. In the paper rolls, germination rates were 64,71 , and $65 \%$, with an increase at $30^{\circ} \mathrm{C}$ and lower values at $25^{\circ} \mathrm{C}$ and $35^{\circ} \mathrm{C}$. Germination rates in vermiculite substrate were $74 \%$ at $25^{\circ} \mathrm{C}, 60 \%$ at $30^{\circ} \mathrm{C}$, and $65 \%$ at $35^{\circ} \mathrm{C}$ (Figure $1 \mathrm{~A}$ ).

The highest germination rates in each substrate were $71 \%$ in sand at $35^{\circ} \mathrm{C}, 71 \%$ in germination paper rolls at $30^{\circ} \mathrm{C}$, and $74 \%$ in vermiculite at $25^{\circ} \mathrm{C}$ (Figure $1 \mathrm{~A}$ ).

The highest germination rates for seedling formation were obtained in sand $(53 \%)$ and vermiculite $(56 \%)$, both at $25^{\circ} \mathrm{C}$.

Germination rates for seedling formation at 25, 30, and $35^{\circ} \mathrm{C}$ were respectively: 53,34 , and $20 \%$ in the sand substrate, 17,16 , and $4 \%$ in germination paper rolls, and 56 , 15 and $8 \%$ in vermiculite (Figure $1 \mathrm{~B}$ ).
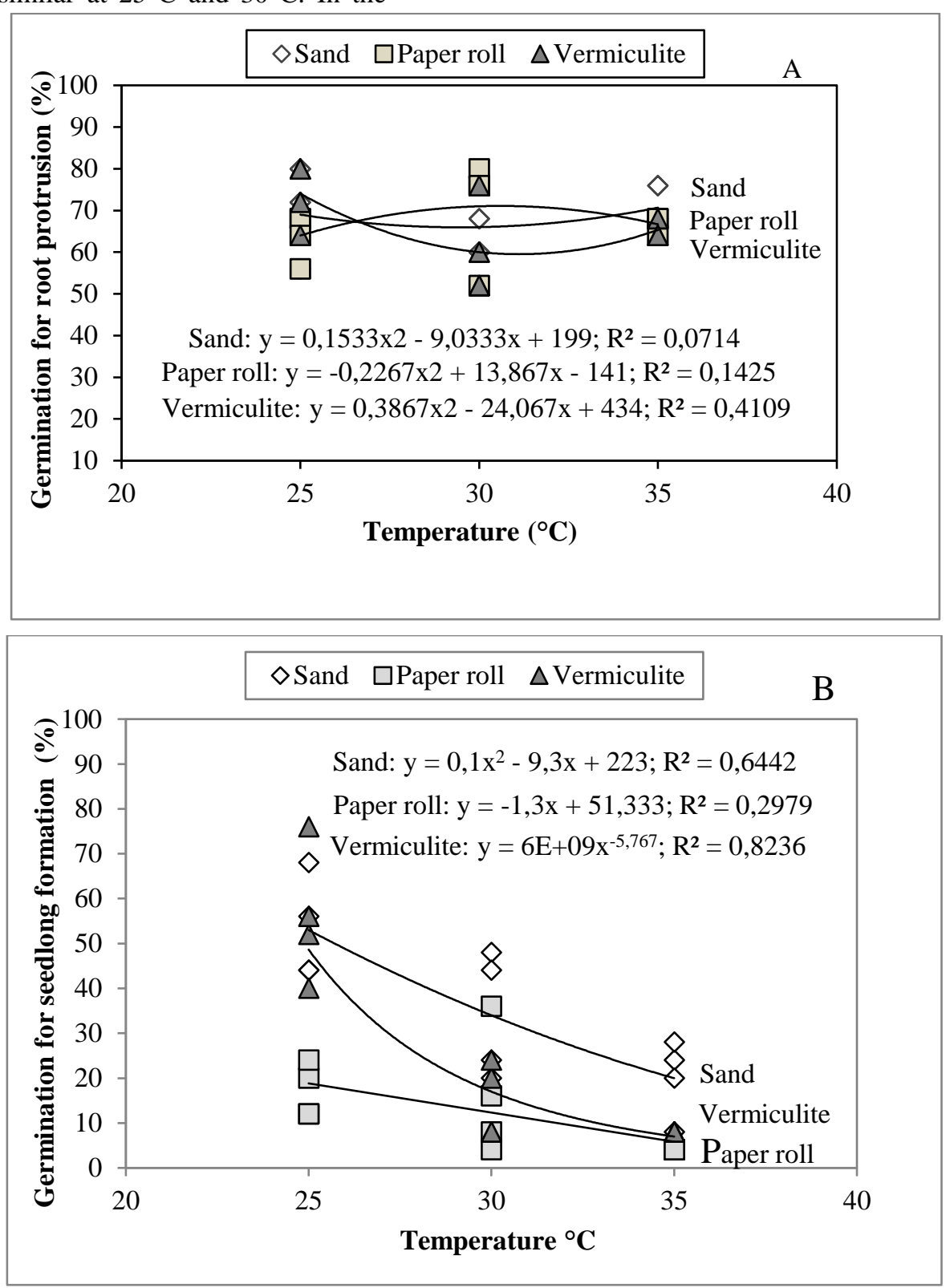

Fig.1 - Germination percentages of Pseudobombax munguba (Mart. \& Zucc.) Dugand. seeds with different temperatures and substrates. A - Root protrusion; B - Seedling formation. 
The highest germination rates for root protrusion show that the time between root protrusion and normal seedling formation at higher temperatures in interaction with substrates reduces the number of germinated plants. Thus, for a large-scale production of $P$. munguba seedlings, seed germination in sand or vermiculite at a temperature of $25^{\circ} \mathrm{C}$ is higher.

The average germination times for root protrusion at temperatures of 25,30 and $35^{\circ} \mathrm{C}$ in the sand substrate were 2.9, 3.4 and 3.0 days, respectively. In paper rolls, these times were $2.7,2.5$ and 2.3 days, whereas in vermiculite, they were 5.4, 3.0 and 4.2 days.

In the sand substrate, the longest time occurred at a temperature of $30^{\circ} \mathrm{C}$ (3.4 days), while the shortest time occurred at the temperature of $25^{\circ} \mathrm{C}$ (2.9 days), which was close to the result found at $35^{\circ} \mathrm{C}$ (3.0 days). In germination paper rolls, these values had less variation $\left(2.7\right.$ days at $25^{\circ} \mathrm{C}$, 2.5 days at $30^{\circ} \mathrm{C}$, and 2.3 days at $35^{\circ} \mathrm{C}$ ). In vermiculite there was greater variation in germination time $\left(5.4\right.$ days at $25^{\circ} \mathrm{C}$, 3 days at $30^{\circ} \mathrm{C}$, and 4.2 days at $35^{\circ} \mathrm{C}$ ) (Figure $2 \mathrm{~A}$ ).
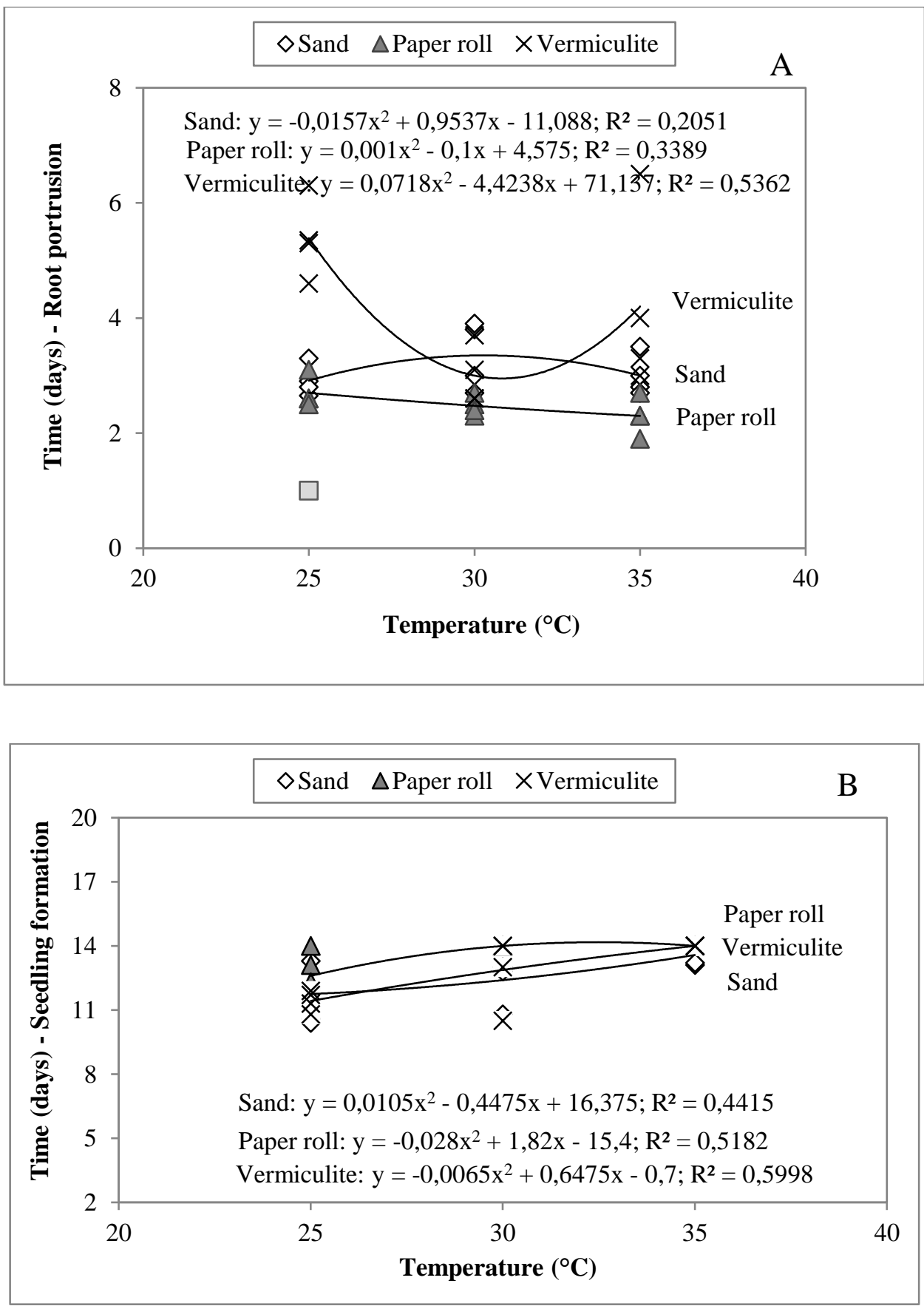

Fig.2 - Mean time (days) for seed germination of Pseudobombax munguba (Mart. \& Zucc.) Dugand. as function of temperature and substrate. A - Root protrusion; B - Seedling formation. 
The average times for seedling formation in the sand substrate were 11.8 days at $25^{\circ} \mathrm{C}, 12.4$ days at $30^{\circ} \mathrm{C}$, and 13.6 days at $35^{\circ} \mathrm{C}$. In germination paper rolls the times were 12.6 days at $25^{\circ} \mathrm{C}, 14.0$ days at $30^{\circ} \mathrm{C}$, and 14.0 days at $35^{\circ} \mathrm{C}$. In vermiculite, the times were 11.4 days at $25^{\circ} \mathrm{C}, 12.9$ days at $30^{\circ} \mathrm{C}$, and 14.0 days at $35^{\circ} \mathrm{C}$ (Figure $2 \mathrm{~B}$ ).

The shortest seedling formation times observed in this study were 11.8 days in the sand substrate, and 11.4 days in vermiculite, both at temperature of $25^{\circ} \mathrm{C}$.

The time difference between root protrusion and seedling formation at $25^{\circ} \mathrm{C}$ was 6 days in vermiculite, and 8.9 days in sand. The longest intervals occurred in germination paper rolls at $30^{\circ} \mathrm{C}(11.5$ days $)$ and $35^{\circ} \mathrm{C}(11.7$ days).
The germination speed index (GSI) values obtained for root protrusion at a temperature of $25^{\circ} \mathrm{C}$ were 4.9 in the vermiculite substrate, 6.1 in sand, and 6.4 in paper rolls. At $30^{\circ} \mathrm{C}$, GSI values were 5.8 in sand and vermiculite, and 7.0 in paper rolls. At $35^{\circ} \mathrm{C}$, GSI values were 6.6 in sand, 7.2 in paper rolls, and 5.0 in vermiculite (Figure 3A).

The GSI values obtained for seedling formation at $25^{\circ} \mathrm{C}$ were 1.2 in the sand and vermiculite substrates, and 0.4 in germination paper rolls. At the temperature of $30^{\circ} \mathrm{C}$, GSI values were 0.7 in sand, and 0.3 in both paper rolls and vermiculite. At $35^{\circ} \mathrm{C}$, GSI values were 0.4 in sand, and 0.1 in both paper rolls and vermiculite (Figure $3 \mathrm{~B}$ ).
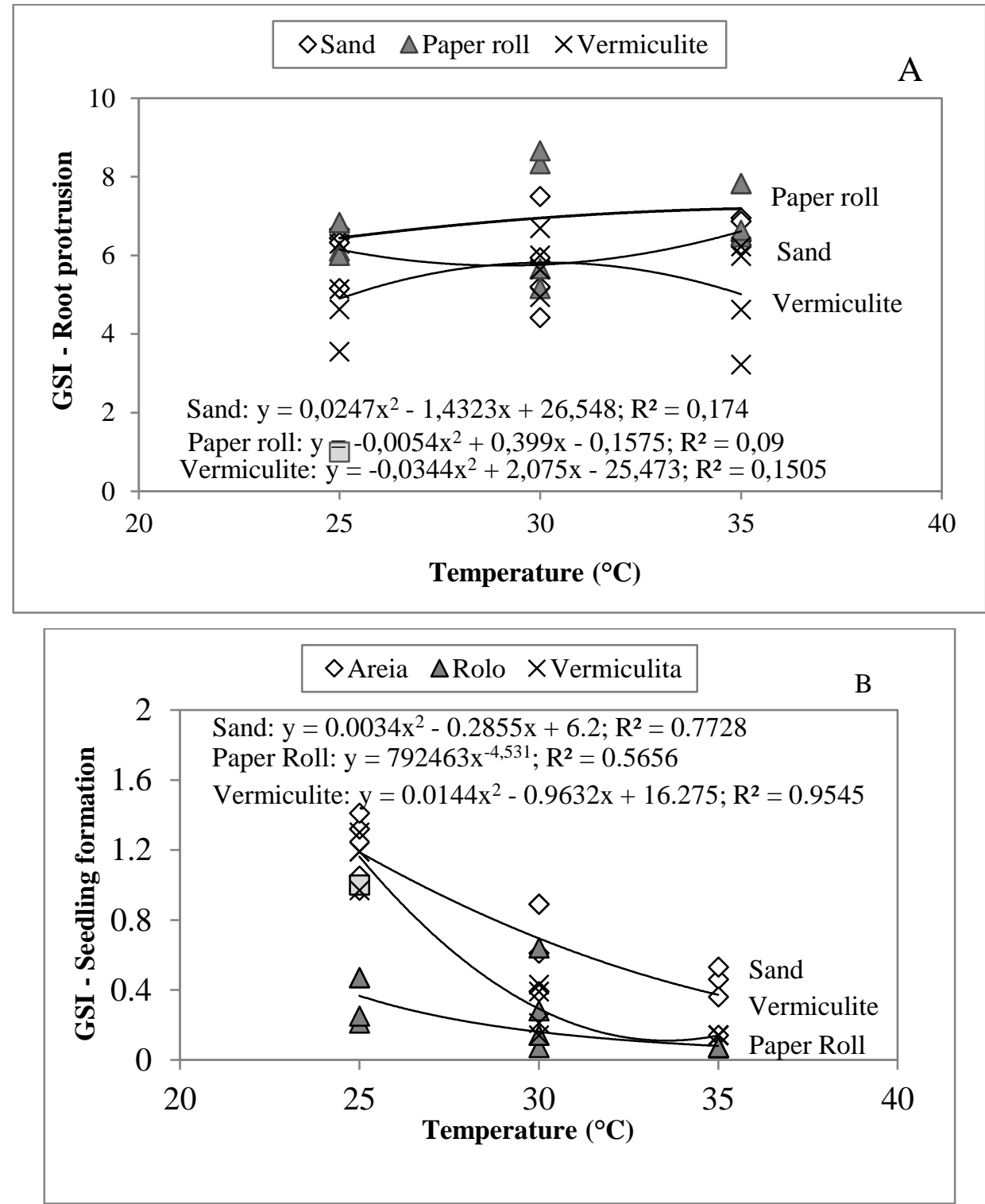

Fig.3 - Germination Speed Index (GSI) of seeds of Pseudobombax munguba (Mart. \& Zucc.) Dugand., obtained with different temperatures and substrates. A - Root protrusion; B - Seedling formation. 
The highest GSI values concerning to root protrusion occurred in the germination paper roll substrate (7.0 at $30^{\circ} \mathrm{C}$, and 7.2 at $35^{\circ} \mathrm{C}$ ). On the other hand, the lowest value (4.9) was observed in the vermiculite substrate at $25^{\circ} \mathrm{C}$. The highest GSI value for seedling formation (1.2) was observed in sand and vermiculite substrates at $25^{\circ} \mathrm{C}$, whereas the lowest value occurred in germination paper rolls (0.07).

The highest germination rates for seedling formation were obtained when using sand and vermiculite substrates at a temperature of $25^{\circ} \mathrm{C}$, which proved to be more efficient than the temperatures of 30 and $35^{\circ} \mathrm{C}$. There were smaller differences in the mean germination time between root protrusion and the formation of seedlings, thus showing greater homogeneity in the germination process of P. munguba seeds.

The lowest germination rates for seedling formation were obtained when using germination paper rolls. The results showed the greatest time differences between root protrusion and seedling formation, the highest GSI values in root protrusion, and also the lowest values in seedling formation at all temperatures of the experiment. Therefore, germination paper rolls are less suitable for $P$. munguba seed germination and seedling formation.

\section{DISCUSSION}

The number of seeds $/ \mathrm{kg}$ of the species $P$. munguba, calculated from its 1000 seed weight $(18,88475$ g) was 52,953 . These results were obtained from the seeds of 5 trees, collected in the same location, on a beach in the city of Manaus.

However, the number of seeds/kg of 67,558 , calculated with data from Meniccuci (2007), was obtained from 16 to 43 individuals of each population in 11 locations in the Amazon: Beruri - AM, Caracarai - RR, Catalão AM, Cruzeiro do Sul - AC, Caxiuanã National Forest - PA, Japurá River - AM, Madeira River - AM, Paraná do Mapixi by Purus River - AM, Tefé - AM, Tabatinga - AM (right bank), and Tabatinga - AM (left bank). Analysis of molecular variance using all populations showed that most of the genetic variation found can be explained by the variation contained within populations $(59 \%)$. When excluding monomorphic populations, this value rose to $66 \%$. Analysis by the Mantel test, which correlates genetic and geographic distances between the populations analyzed in pairs, indicated that there is no isolation by distance between the populations of $P$. munguba in the Brazilian Amazon.

Given the above, these differences can be understood by the potential genetic variability that must exist in the species. Gribel and Gibbs (2002) reported that although $P$. munguba does not have a conventional mechanism for stigmatic or stylar self-incompatibility, the combination of exclusive pollination by a wide-ranging bat vector and the death of most self-fertilized eggs provide this species with an outcrossing breeding system.

The result of $7.2 \%$ moisture in the treatment with 50 seeds, which showed the smallest standard deviation $(0.13 \%)$ and a $0.3 \%$ difference between replicates, made it possible to consider it as the most representative treatment for moisture evaluation with this number of $P$. munguba seeds. According to the Seed Analysis Rules (Brasil, 2009), when the number of seeds $/ \mathrm{kg}$ is greater than 5,000 , the difference between replicates must be lower than $0.6 \%$, which happened in this treatment, since the difference was $0.3 \%$. Germination rates for the formation of seedlings also showed the highest values in sand or vermiculite substrates at a temperature of $25^{\circ} \mathrm{C}$, and inferior results at 30 and $35^{\circ} \mathrm{C}$. There were smaller differences in the mean germination time between root protrusion and seedling formation, and there was greater homogeneity in the germination process of $P$. munguba seeds. Similar results were found by Ladeia et al. (2011) and Ladeia et al. (2012) in the germination of a species of the same genus as P. munguba (Pseudobombax longiflorum). The authors concluded that the most suitable treatment for the production of seedlings was by using sand substrate at a temperature of $30^{\circ} \mathrm{C}$.

A treatment with sand at a temperature of $25^{\circ} \mathrm{C}$ also resulted in higher rates of Acosmuim nitens seed germination and seedling formation (Varela et al., 2005). Barbosa (1995) also found higher seed germination rates at $25^{\circ} \mathrm{C}$ with the species Rheedia benthamiana $\mathrm{P}$ er Tr. and Couroupita guianansis Aubl. for the production of seedlings used in revegetation in areas affected by a hydroelectric power plant. Those plants, similarly to $P$. munguba also grow naturally on the banks of watercourses in the Amazon.

\section{CONCLUSIONS}

The species Pseudobombax munguba has 52,953 seeds $/ \mathrm{kg}$ and its seeds have water content between 6.4 and $8.5 \%$. When germinated under controlled conditions, in sand or vermiculite substrates at a temperature of $25^{\circ} \mathrm{C}$, they reached the highest germination percentages (53 to $56 \%$ ), the most homogeneous initial development of seedlings, higher GSI levels, and a large number of seeds per $\mathrm{kg}$. This species has become highly important for riverside populations, as well as for reforestation or the recovery of areas degraded by deforestation along watercourses in the Amazon. 


\section{REFERENCES}

[1] Barbosa, A.P. 1995. Estudos de espécies florestais amazônicas visando a revegetação de áreas de depleção da usina hidrelétrica de Camargos, Itutinga, MG. Tese de Doutorado; Universidade Federal de Lavras, MG. 96 p.

[2] Brasil. 2009. Regras para Análise de Sementes. Ministério da Agricultura e Reforma Agrária. SNDA/DNDV/CLAV, Brasília, 395pp.

[3] Ferreira, A. G.; Borghetti, F. Germinação: do básico ao aplicado. Porto Alegre: Artmed, 2004. 323 pp.

[4] Gribel, R. 2003. Polinização por morcegos em Bombacaceae: Consequiências para o sistema reprodutivo e estrutura genética das populações. In: Jardim, M.A.G.; Bastos, M.N.C.; Santos, J.U.M. (Eds.). $54^{\circ}$ Congresso Nacional de Botânica, 2003, Belém. Desafios da Botânica no Novo Milênio: Inventário, Sistematização e Conservação da Diversidade Vegetal. MPEG, UFRA, EMBRAPA, Belém, PA. p.108-110.

[5] Gribel, R. 2005. Reproductive biology of two bombacaceae trees in the Brazilian Central Amazon. Doctor of Philosophy's Thesis. University of St. Andrews, United Kingdom, $185 \mathrm{p}$.

[6] Gribel, R.; Gibbs, P.E. 2002. High outbreeding as a consequence of selfed ovule mortality and single vector bat pollination in the Amazonian tree Pseudobombax munguba (Bombacaceae). International Journal of Plant Sciences, 163(6):1035-1043.

[7] Ladeia, E.S.; Coelho, M.F.B.; Azevedo, R.A.B. 2011. Germinação de sementes de Pseudobombax longiflorum (Mart. \&Zucc.) A. Robyns. (Malvaceae) de duas procedências em diferentes temperaturas. Revista de Ciências Agrárias, 54(3): 290-298.

[8] Ladeia, E.S.; Coelho, M.F.B.; Azevedo, R.A.B.; Albuquerque, M.C.F. 2012. Procedência do fruto e substratos na germinação de sementes de Pseudobombax longiflorum (Mart. \&Zucc.) A. Robyns. Pesquisa Agropecuária Tropical, 42(2): 174-180.

[9] Maguire, J. O. 1964. Speed of germination and in selection and evaluation for seedling emergence and vigor. Crop. Science, 2(2):176-177.

[10] Maia, L.M.A. 2001. Frutos da Amazônia: fonte de alimentos para peixes. Programa de Desenvolvimento Empresarial e Tecnológico. INPA, SEBRAE/AM. Manaus. 143 pp.

[11] Menicucci, T.A. 2007. Fitogeografia e estrutura genética de populações de mungubeira (Pseudobombax munguba Mart \& Zucc.) Dugand, Malvaceae - Bombacoideae) na Amazônia Brasileira. Dissertação. Mestrado em Genética, Conservação e Biologia Molecular. INPA/UFAM - Programa Integrado de Pós-Graduação em Biologia Tropical e Recursos Naturais. 66pp.

[12] Poulsen, K.M.; Parrat, M.J.; Gosling, P.G. (Eds.). Topical and subtropical tree and shrub seed handbook. Zurich: ISTA, 1998. 204p.

[13] Santana, D.G.; Ranal, M.A. 2004. Análise estatística. In: Ferreira, A.G.; Borguetti, F. (Eds.). Germinação: do básico ao aplicado. Artmed, Porto Alegre. p.197-208.
[14] Varela, V.P.; Costa, S.S.; Ramos, M.B.P. 2005. Influência da temperatura e do substrato na germinação de sementes de itaubarana (Acosmium nitens (Vog.) Yakovlev) Leguminosae, Caesalpinoideae. Acta Amazonica, 35(1): 3539. 